\title{
Millimeter-Wave Standards: An Emerging Need
}

\author{
ROBERT T. ADAIR, SENIOR MEMBER, IEEE, GEROME R. REEVE, SENIOR MEMBER, IEEE, \\ AND L. E. GATTERER, SENIOR MEMBER, IEEE
}

\begin{abstract}
Several technology surveys concerning millimeter-wave (MMW) measurement needs and capabilities have been conducted by the National Bureau of Standards (NBS), Boulder Laboratories, and others. The results of some of these studies are summarized. Current MMW standards and calibration capabilities at NBS are reviewed. The lack of national standards in certain frequency bands may lead to problems with the specification, acceptance testing, and calibration of some components and systems.
\end{abstract}

\section{INTRODUCTION}

$\mathrm{N}$ EW communications and navigation technologies using satellites and more complex military systems of all kinds require better measurement support at higher frequencies. Proper assessment of component and system performance requires an adequate metrology base to assure consistent, correct performance of hardware and measurement instrumentation. Frequently, system designers and staff developing new systems do not make their metrology needs known early in their programs. Thus the National Bureau of Standards (NBS) is often unaware of new metrology needs until a formal request for calibration is received. Specific efforts are now being made, particularly within the Department of Defense (DoD), to acquaint program managers and contractors with the need to plan and coordinate metrology support requirements in the early stages of new programs. Also, NBS and other groups have conducted surveys of industrial and military laboratories to determine upcoming needs in millimeterwave (MMW) metrology. Finally, various initiatives are under way to secure increased support for developing new and improved microwave (MW) and MMW standards and services at NBS.

\section{BACKGROUND}

Within NBS, the Electromagnetic Fields Division of the Center for Electronics and Electrical Engineering is responsible for conducting research in, and developing standards for, MW and MMW metrology. This research is supported primarily by two sources: congressionally appropriated funds and funds from other government agencies for specific projects. The Office of Management and Budget (OMB) has rules that where metrology needs are generated by other government agencies, those federal

Manuscript received March 25, 1986.

The authors are with the National Bureau of Standards, Boulder, CO 80303

IEEE Log Number 8610600. agencies are required to provide the necessary support [1]. Since the DoD often requires metrology support in advance of industrial needs, a special channel was created to provide this support. The Calibration Coordination Group (CCG) of the Joint Technical Coordination Group (JTCG) of the three Armed Services works closely with $\mathrm{N}$; $\mathrm{S}$ to insure that existing and yet to be fielded equipment will be supported by adequate standards and measurement services.

As a result of congressional action there has been a modest increase in the congressionally appropriated funds for MW and MMW work for fiscal year 1986 and succeeding years. Although this is not sufficient to fulfill all of the needs that exist in MMW standards at NBS, it has enabled NBS to start work in several areas and expedite work already under way.

Technology continues to develop at an ever-increasing rate into higher portions of the frequency spectrum. This generates increasing needs for standards and measurements in the MMW region. Determining the real measurement needs of industry and the military and assessing the priority of these needs with respect to the national measurement system is a very difficult task. A number of significant surveys and studies have been conducted during the past several years as a means of identifying the required measurement parameters, frequencies, priorities, and the extent of these needs. In April 1985 the preliminary report of the Committee to Promote National Microwave Standards (PNMS) was released [2]. This committee is an ad hoc committee of the IEEE Microwave Theory and Techniques Society (MTT-S) and is composed of industry representatives from firms highly active in the MW and MMW areas. After conducting a survey of measurement needs as perceived by industry and DoD and assessing NBS capabilities, PNMS documented these requirements and priorities (see Table I). The ultimate objective of the PNMS Committee is to draw attention to the needs for MW and MMW standards.

The National Measurement Requirements Committee (NMRC) of the National Conference of Standards Laboratories (NCSL) conducted a national measurement requirements survey beginning in 1982 . Over 1400 U.S. companies, government organizations, and universities were surveyed to assess the overall national measurement requirements. This National Measurement Requirements Survey was published in May 1983 [3] and was subsequently used as a major source document by the PNMS committee. The objectives of the NCSL survey were: 
TABLE I

SUMMARY OF PNMS RECOMMENDATIONS FGR STANDARDS AND

Calibration Services

\begin{tabular}{|c|c|c|c|c|c|c|c|c|c|c|}
\hline \multirow{2}{*}{\multicolumn{2}{|c|}{ PARAMETEA }} & \multicolumn{2}{|c|}{ COAXIAL } & \multicolumn{7}{|c|}{ WAVEGUIDE } \\
\hline & & \multirow{2}{*}{$\begin{array}{c}\text { C180H } \\
7 \mathrm{~mm} \\
A\end{array}$} & \multirow{2}{*}{$\begin{array}{l}\frac{628 \mathrm{GHz}}{3.5 \mathrm{~mm}} \\
\wedge\end{array}$} & \multirow{2}{*}{$\begin{array}{l}\begin{array}{l}<18 \\
\mathrm{GHz}\end{array} \\
\mathrm{B}\end{array}$} & \multirow{2}{*}{$\begin{array}{l}\begin{array}{r}1826 \\
\mathrm{GHz}^{2}\end{array} \\
A\end{array}$} & \multirow{2}{*}{$\begin{array}{l}\begin{array}{l}2640 \\
6 H_{2}\end{array} \\
8\end{array}$} & \multirow{2}{*}{$\begin{array}{c}\begin{array}{c}3350 \\
\text { GH2 }\end{array} \\
A\end{array}$} & \multirow{2}{*}{$\begin{array}{l}\begin{array}{l}5075 \\
\text { GHz }\end{array} \\
C\end{array}$} & \multirow{2}{*}{$\begin{array}{l}\begin{array}{l}75110 \\
\mathrm{GHz}_{2}\end{array} \\
\mathrm{C}\end{array}$} & \multirow{2}{*}{$\begin{array}{l}2110 \\
\text { GH1 } \\
0\end{array}$} \\
\hline 1 & IMPEDANCE & & & & & & & & & \\
\hline 2 & ROWEA & A & B & B & B & c & $\wedge$ & D & c & D \\
\hline 3 & THEAMAL NOISE & B & 8 & $\mathbf{B}$ & $\mathbf{B}$ & B & B & D & D & $\mathbf{F}$ \\
\hline 4 & ATTERUATION & B & c & c & D & D & B & c & c & $\mathbf{F}$ \\
\hline 6 & HIGH POWEA & c & c & c & E & E & c & G & $\mathbf{F}$ & G \\
\hline 6 & ANTENNA & - & - & E & E & E & c & G & G & H \\
\hline 7 & POWER DENSITY & - & - & D & o & $\mathbf{F}$ & D & H & G & H \\
\hline - & $\begin{array}{l}\text { FAEOUENCY } \\
\text { IPHASE NOISE AND SWITCH. } \\
\text { ING SPEEDI }\end{array}$ & - & - & D & $\mathbf{F}$ & $\mathbf{F}$ & D & H & G & H \\
\hline 9 & PHASE & D & G & D & G & G & D & H & H & H \\
\hline
\end{tabular}

TABLE II

SUMmary of Navy MMW Standards and Calibration NEEdS

\begin{tabular}{|c|c|c|c|c|c|c|c|c|c|c|c|c|c|c|}
\hline $\begin{array}{l}\text { Band } \\
\text { Coa } x / \text { wC }\end{array}$ & $\begin{array}{l}\text { Freq. } \\
\text { Range } \\
\mathrm{CHz}\end{array}$ & $\begin{array}{l}\text { Antenna } \\
\text { Paran- } \\
\text { oters }\end{array}$ & $\begin{array}{l}\text { White } \\
\text { Nolse }\end{array}$ & Power & $\begin{array}{l}\text { Circult } \\
\text { Paraw } \\
\text { eters }\end{array}$ & $\begin{array}{l}\text { Pulse } \\
\text { Power }\end{array}$ & $\begin{array}{l}\text { Mater lals } \\
\text { Propertles }\end{array}$ & $\begin{array}{l}\text { Phase } \\
\text { Nol se }\end{array}$ & $\begin{array}{c}\text { Fleld } \\
\text { Strength }\end{array}$ & $\begin{array}{l}\text { Wave } \\
\text { Fora } \\
\text { Fast } \\
\text { Pulso }\end{array}$ & $\begin{array}{l}\text { Phase } \\
\text { Shife }\end{array}$ & $\begin{array}{l}\text { H1ch } \\
\text { Poser }\end{array}$ & $\begin{array}{c}\text { A.M. } \\
\text { Nol se }\end{array}$ & $\begin{array}{l}\text { Radar } \\
\text { Croos } \\
\text { Section }\end{array}$ \\
\hline $3.5 \mathrm{~mm}$ & $18-26$ & $x$ & $x$ & $x$ & $x$ & $x$ & $x$ & $x$ & $x$ & $x$ & $x$ & $x$ & $x$ & $x$ \\
\hline $3.5 \mathrm{~mm}$ & $26-40$ & $x$ & $x$ & $x$ & $x$ & $x$ & $x$ & $x$ & & $x$ & $x$ & $x$ & & $x$ \\
\hline WA 12 & $18-26$ & $x$ & $x$ & $x$ & $x$ & $x$ & $x$ & $x$ & $x$ & $x$ & $x$ & $x$ & $x$ & $x$ \\
\hline WR 28 & $26-40$ & $x$ & $x$ & $x$ & $x$ & $x$ & $x$ & $x$ & & $x$ & $x$ & $x$ & & $x$ \\
\hline UR 22 & $33-50$ & & & & & & & & & & & & & \\
\hline WR 19 & $40-60$ & $x$ & $x$ & $x$ & $x$ & $x$ & $x$ & $x$ & & $x$ & $x$ & $x$ & $x$ & $x$ \\
\hline UR 15 & $50-75$ & & & & & & & & & $x$ & & & & \\
\hline UR 12 & $60-90$ & $x$ & $x$ & $x$ & $x$ & $x$ & $x$ & $x$ & & & & $x$ & & $x$ \\
\hline WR 10 & $75-110$ & $x$ & $x$ & $x$ & $x$ & $x$ & $x$ & $x$ & $x$ & & $x$ & 94 & & \\
\hline WR 8 & $90-140$ & & & & & & & & & & & & & \\
\hline
\end{tabular}

a) identify requirements for new or improved calibration services from NBS that are necessary for national interests including commerce, international competitiveness, and defense preparedness; and

b) identify new measurement requirements to establish or improve technical, quality, and productivity aspects of individual organizations.

The Tri-Service Metrology Research, Development, and Engineering Plan was published by the Engineering Working Group (EWG) of the CCG on June 6, 1984. This five-year plan is the most current summary of the DoD metrology and calibration (METCAL) needs requiring measurement standards and technology to provide calibration support for new, technically advanced systems [4].

During fiscal year 1985, NBS assisted the Navy in identifying present and future needs for MMW standards and measurement services. A team surveyed a number of projects in naval laboratories and visited prime contractors working on the development of Navy and other DoD MMW systems. The results of the survey are unclassified, and were presented in a report to the sponsor. This information is summarized in Table II.

NBS assisted the Army in fiscal years 1985 and 1986 to identify present and future needs for MMW standards 
and measurement services. A survey team visited the Army Test, Measurement, and Diagnostic Equipment (TMDE) Support Group (TSG) to gather measurement requirements data.

Concerns have been expressed regarding the lack of widespread use of MMW technology in U.S. military applications. Military threats from the Soviets are said to exist since their military systems in the MMW region are more advanced than those of the U.S. [5].

Other disciplines and programs which require $\mathrm{MMW}$ measurements support include radio astronomy [6], NASA Advanced Communications Technology Satellite (ACTS) [7], [8], and university research laboratories [9].

There appears to be increased activity in MMW technology in the private sector in addition to the areas already discuss $J$. This is made evident by the large number of technical papers on MMW theory, component development, and measurement techniques which were presented at recent technical conferences [10]-[13].

\section{Millimeter-Wave Standards and Measurement NeEdS}

The expanding research and development in MMW technology has created a basis for accelerating the development of new systems and devices. While these advances in technology appear to offer greatly improved system capabilities, they add significantly to the complexity of. and technical requirements for, traceability and calibration support. There are currently no national standards for certain electrical quantitites that are critical to the specification, construction, acceptance testing, and calibration of systems which are now, or will be, critical to industry, government, and DoD needs. Thus the required traceability to national standards is presently not available [14]. [15].

As previously mentioned, the PNMS Committee identified $\mathrm{MW}$ and $\mathrm{MMW}$ measurement requirements, summarized in Table I. This table lists the desired parameters, transmission media, and frequencies. with the priorities based on industry needs for the development of these capabilities. The requirements depicted in this table represent not only the needs of industry but those expressed by corporate suppliers of military systems as well. In addition the PNMS Committee obtained information concerning military measurement needs directly from the CCG. Further information was gathered by the CCG and the PNMS committees at recent classified seminars on MMW measurement requirements. These seminars were organized jointly by DoD and NBS [16], [17].

A summary of the MMW programs identified by the NCSL NMRC is presented in Table III. Definitions of most of the abbreviated program names in the table appear in $[2$, p. $2 \mathrm{C}-14]$. These programs are either under development or are ready for full-scale development.

These military programs are only a partial listing since classified programs cannot be published. However, the NCSL study indicates that potential requirements exist from 33 through $120 \mathrm{GHz}$.
TABLE III

SUMMARY OF NCSL LISTING OF UNCLASSIFIED MILITARY Programs NeEding MEasurement Support at the INDICATED MMW FREQUENCIES

\begin{tabular}{lc}
\hline & \\
$\begin{array}{l}\text { PROGRAM NAME OR } \\
\text { ABBREVIATION }\end{array}$ & $\begin{array}{c}\text { FREQNCY } \\
\text { IN GHZ }\end{array}$ \\
\hline MILSTAR Payload & 44,20 \\
MILSTAR Terminals & 44,20 \\
ESAAP & 30,20 \\
DSCS UPgrades & 44 or 30,20 \\
SCOTT & 44,20 \\
NESP & 44,20 \\
NASA Satellites & 30,20 \\
CROSSLINKS & 60 \\
STARTLE & 94 \\
TAMS & 94 \\
SenSor Blencing & 35 or 94 \\
MTAS & 94 \\
& \\
\hline
\end{tabular}

TABLE IV

SLMMARY OF CCG LISTING OF UNCLASSIFIED MILITARY Programs Needing Measurement Support at the INDICATED MMW FREQUENCIES

\begin{tabular}{lc}
\hline \hline PRCGRAM NAME OR & FREQUENCY \\
ABEREVIATION & IN GHZ \\
\hline MILSTAR & 20.7 \\
MILSTAR & 44.0 \\
- & $18-46$ \\
MILSTAR & 60.0 \\
- & $55-65$ \\
- & $94-96$ \\
- & 140 \\
- & 220 \\
\hline
\end{tabular}

TABLE V

Partial listing of Unclassified army MMW Programs Needing Measl rement Support at the Indicated MMW Frequencies

\begin{tabular}{lc}
\hline \hline PROGRAM NAME OR. & FREQUENCY \\
ABEREVIATION & IN CHZ \\
\hline \multirow{2}{*}{ TCN-WCL } & 35 \\
SADARM & 35 \\
- & $36,94,140$ \\
MLRS & \multicolumn{2}{c}{94} \\
\hline
\end{tabular}

A brief summary of the MMW metrology requirements taken from the Tri-Service Metrology Research, Development, and Engineering Plan appears in Table IV. Classified programs cannot be included in this table. However, this CCG EWG document states that most measurement support requirements lie in the frequency range from 18 to $325 \mathrm{GHz}$.

Table $\mathrm{V}$ is a summary of some of the unclassified Army systems which need MMW measurement support (by the TMDE Support Group (TSG) and therefore by NBS).

Table VI is a summary of MMW weapon and communications systems and their general operating frequencies. It has been reported that far more effort should be expended in the U.S. to develop, field, and support systems of this type which operate well into the MMW region [5].

The Navy has current and/or projected needs for standards and measurement services for power, pulse power, attenuation, reflection coefficient, $S$ parameters, antenna 


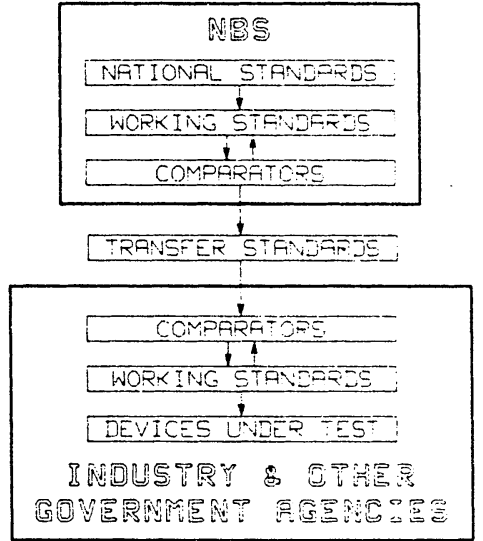

Fig. 1. Typical method of calibratioun transfer for national measurement support

TABLE VI

TyPiCal MMW WEapon and COMMUNications SySTEMS AND Their Nominal Operating Frequencies

\begin{tabular}{|c|c|}
\hline $\begin{array}{l}\text { SYSTEM NAME OR } \\
\text { ABBREV IATION }\end{array}$ & $\begin{array}{c}\text { FREQUENCY } \\
\text { IN GHZ }\end{array}$ \\
\hline $\begin{array}{l}\text { SATCOM UPlinks } \\
\text { RWR's, SADARM, } \\
\text { MUIti-mOde GuIdance } \\
\text { SATCOM UPlInK, WASP } \\
\text { INTERSATCOM } \\
\text { QUIET RADAF, BEAMRIDER } \\
\text { BEAMRIDER, PROJECTILES } \\
\text { QUIET RADAR, SMART BULLET } \\
\text { MISS ILE GUIDANCE }\end{array}$ & $\begin{array}{r}20-35 \\
33-94 \\
33-94 \\
44=94 \\
50-140 \\
94=240 \\
120-240 \\
f \geq 240 \\
f \geq 240\end{array}$ \\
\hline
\end{tabular}

gain and polarization, antenna near-field patterns, whitenoise sources, phase noise, various properties of materials, fast pulses, and amplitude modulation noise in the MMW region. Table II presents a summary of these needs. These parameters are arranged in order of priority using available unclassified information. Although separate similar in-depth studies have not been conducted by NBS specifically for the Air Force and the Army, the information contained in Table II is believed to be representative of most military needs.

A careful examination of Tables I-VI reveals a considerable range of parameters and frequencies in the $\mathrm{MMW}$ region, for which measurement support is needed.

\section{National Measurement Support Structure}

While many end users of measurement instruments and systems are unaware of their traceability to NBS, contractors performing work for the military are required to show traceability of such measurements to NBS. This typically results in consistent measurements and standards throughout the industrial segment. The flow diagram in Fig. 1 illustrates, in general terms, how most industry and DoD laboratories utilize NBS measurement support services. The flow diagram ${ }^{1}$ in Fig. 2 illustrates how the various standards laboratories and measurement levels within

Adapted from The National System for Electricity (NBSIR 75-935) issued September 1978.

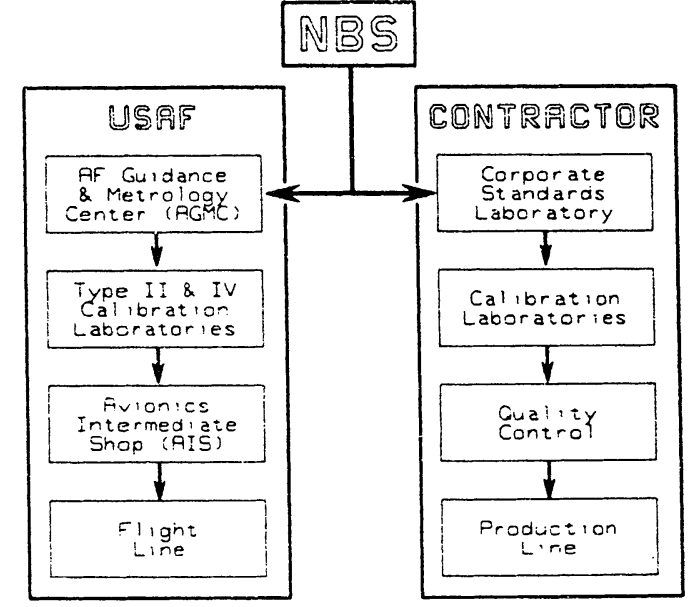

Fig. 2. Typical method of calibration transfer for military measurement support (Air Force flight line).

large corporations or military organizations obtain traceability to NBS and thereby ensure measurement agreement on the production line or flight line. The example in Fig. 4 is specific to the Air Force flight line support, but similar support structures exist for other branches of the military system.

\section{Present Capabilities of NBS}

NBS offers measurement services to support the national measurement system portrayed in Figs. 1 and 2 . Available NBS measurement services are listed in NBS Special Publication (SP) 250 [18], which includes special test services arranged on an individual basis. The status of NBS physical measurement services is presented in [19]. Table VII summarizes the present capabilities of NBS MW and MMW standards and calibration services as of December 1985. The various symbols indicate the status of individual services by frequency band. Several activities are under way to fill in or improve coverage in the MMW area, although there are still many waveguide bands in which work has yet to be initiated.

\section{Vi. Planned Expansion and Development of \\ Millimeter-Wave Standards, Measurements, and Calibration Services at NBS}

The increased nationwide emphasis on MMW technology has helped to focus and accelerate the planning for the continuing development of the national metrology base. The industry and military measurement needs, discussed previously, and specific requests for MMW measurement services at NBS, are helping to influence the prioritization of technical programs to meet these needs.

Referring again to Table VII, we note that planning has been initiated for the construction of a new calorimetric power standard in the $33-50-\mathrm{GHz}$ waveguide band. While this will be based upon the designs used in the older standards in the MW region, and upon experience with the WR-10 microcalorimeter, new materials and designs for temperature stabilization will be examined. Construction 


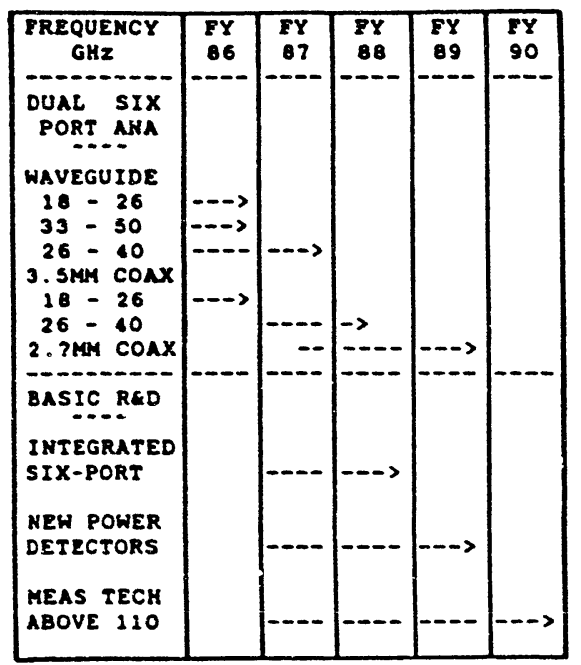

Fig. 3. Plans for circuit parameter measurement services.

TABLE VII

Simmary of NBS MW avd MMW Standards and Calibration Services

\begin{tabular}{|c|c|c|c|c|c|c|c|c|c|c|c|c|c|}
\hline \multirow{2}{*}{$\begin{array}{l}\text { O full } \\
\text { O Mono } \\
\text { Iand } \\
\text { Coss/wC }\end{array}$} & \multicolumn{2}{|c|}{$\begin{array}{l}\text { O Partial } \\
\text { O Ad-Hoc. limised }\end{array}$} & \multicolumn{3}{|c|}{ 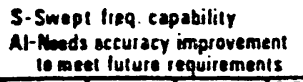 } & \multicolumn{3}{|c|}{ 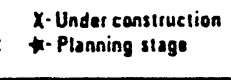 } & \multicolumn{5}{|c|}{$\begin{array}{l}\text { U-Eqpmi updtg. nesded lor incrsed sives. } \\
\text { IF-Limiled fieg. covorage }\end{array}$} \\
\hline & $\begin{array}{l}\text { Froe } \\
\text { Rang } \\
\text { CHil }\end{array}$ & \begin{tabular}{|c|}
$\begin{array}{c}\text { Powor } \\
\text { Standare } \\
\sharp\end{array}$ \\
\end{tabular} & $\begin{array}{l}\text { Pulse } \\
\text { Powers }\end{array}$ & $\begin{array}{c}\text { Alten. } \\
\text { uetion } \\
\end{array}$ & \begin{tabular}{|c|}
$\begin{array}{c}\text { Roflece. } \\
\text { Coet. } \\
\sharp\end{array}$ \\
\end{tabular} & \begin{tabular}{|c|}
5 Param \\
6 Port \\
single or \\
dulal \\
\end{tabular} & $\begin{array}{l}\text { Anten } \\
\text { Gain \& } \\
\text { Pol. }\end{array}$ & $\mid \begin{array}{l}\text { Panses } \\
\text { Pation } \\
\end{array}$ & $\left|\begin{array}{l}\text { White } \\
\text { noise } \\
\text { sourcess }\end{array}\right|$ & Phase & 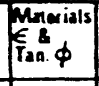 & $\begin{array}{l}\text { Wave } \\
\text { lorni } \\
\text { tast } \\
\text { pulse }\end{array}$ & $\begin{array}{l}A M \\
\text { noise }\end{array}$ \\
\hline 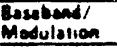 & & & & & & & & & & 0 & & & 0 \\
\hline $2 \mathrm{~mm}$ & 1.18 & $R_{1}$ & 0 & $\Omega_{1}$ & $\overline{Q_{1}}$ & Dual & $\xi$ & $\theta$ & $\begin{array}{l}9 x \\
2-1 \mathrm{GHz}\end{array}$ & 0 & 0 & & \\
\hline $35 \mathrm{~mm}$ & $18-26$ & o* & 0 & 0 & 0 & $0 x / 166$ & 8 & 0 & 10 & & 0 & & \\
\hline $35 \mathrm{~mm}$ & $26 \cdot 40$ & D* & 0 & 0 & O & \begin{tabular}{|l}
$\delta_{0}^{*}$ \\
Dual
\end{tabular} & 8 & 8 & 0 & & 10 & & \\
\hline WR so & . 1.12 & 0 & 0 & - & 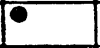 & 0 & s & - & 8 & & 0 & & \\
\hline WR 62 & 12.18 & 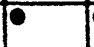 & 0 & • & 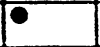 & 0 & s & $\bullet$ & 8 & & 10 & & \\
\hline WR 42 & 18.26 & 0 & 0 & ? & 9 & $\sigma_{1 / 26}$ & s & 0 & ox & & To & & \\
\hline WR 28 & $25-40$ & 0 & 0 & $\theta$ & 0 & 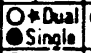 & iv & $i$ & 0 & & 0 & & \\
\hline WR 22 & 33.50 & $0 *$ & 0 & 0 & 0 & 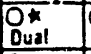 & $0 x$ & $O x$ & $0 x$ & & 0 & & \\
\hline WR IS & 40.60 & $0 *$ & 10 & 0 & 0 & $O^{*}$ & 0 & 0 & 0 & & 0 & & \\
\hline WR 15 & 50.75 & OLf & 0 & OLF & Olf & \begin{tabular}{|l} 
OLff \\
Single
\end{tabular} & 0 & 0 & 8 Lf & & 0 & & \\
\hline WR 12 & 60.90 & 0 & 0 & 0 & o & $0^{\circ}$ & 0 & 0 & 0 & & 0 & & \\
\hline WR 10 & $75 \cdot 110$ & 090.96 & 10 & 094.96 & 09.96 & \begin{tabular}{|l|} 
O94.-96 \\
Oual
\end{tabular} & 0 & 0 & $099-96$ & & 0 & & \\
\hline WR: & 90.140 & & & & & & & & & & & & \\
\hline Pallen. & Co & & Int & & & & & & & $+m_{0}$ & casured by & near tielo & d iochont \\
\hline
\end{tabular}

is nearing completion on the $18-26-\mathrm{GHz}$ dual six-port network analyzer and planning has started on the 26-40and $33-50-G H z$ six ports. The use of these six ports will allow measurements to be made on devices using coaxial connectors (by means of adapters) as well as on devices with waveguide flanges. In addition, it will permit the existing waveguide calorimetric power standards in the 1826- and $26-40-\mathrm{GHz}$ bands to be used to calibrate coaxial components. A new dual six-port calibration technique has been developed which will enable coaxial components with any combination of connectors to be measured and evaluated.

Several studies are now under way to further analyze the errors in six-port measurements which should enable connector repeatability errors to be separated from those inherent in the six-port system. Although this work is being performed and tested on the MW systems, it will apply equally well to the MMW systems and thereby accelerate their development. The results and techniques obtained from this work will allow future calibrations to be performed and reported more accurately. The milestone chart which appears in Fig. 3 summarizes the current plans for basic $R$ \& $D$ expansion of measurement services $^{2}$ in MMW's at NBS for the measurement of circuit parameters and scattering parameters.

An antenna measurement system is being expanded to

"Measurement services at NBS consist of both "special test services" which have not been fully reviewed by the NBS Calibration Committee (CALCOM), and "calibration services" which have been fully reviewed and approved by CALCOM. 


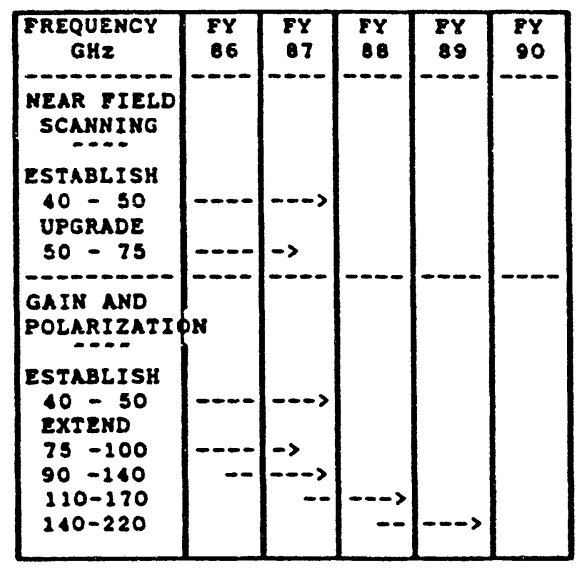

Fig. 4. Plans for antenna measurement services.

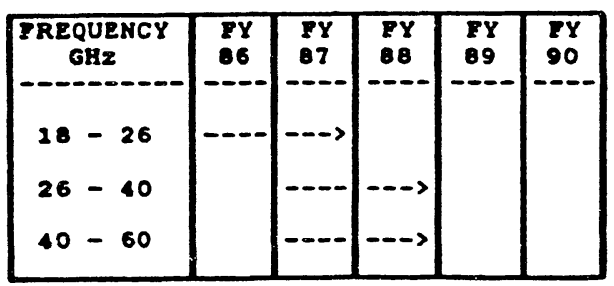

Fig. 5. Plans for noise measurement services.

support national requirements in the $33-50-\mathrm{GHz}$ band. Completion is scheduled for late 1987. Increased demand for services in several other bands requires updating of equipment, which is at present unfunded. Fig. 4 illustrates the specific plans for expanding the antenna measurement services.

Of particular importance is the development of a measurement technique, derived from six-port theory, which allows the calibration of a customer noise standard in which the connector differs from that of the NBS reference standard, with minimum added uncertainty. A description of this work is scheduled to be published as an NBS Technical Note late in 1986. This emphasizes the need for replacing older tuned switching radiometers in the $\mathrm{MW}$ region with the new automated versions incorporating a six-port analyzer. When developed fully, similar techniques will be applied in the Miviw region. Work is currently being performed to develop thermal noise standards in the 18-26- and 33-50-GHz frequency ranges in support of MILSTAR activities. Some preliminary services may be available in the lower band by the end of 1986. Fig. 5 is a milestone chart showing the planned future activity in noise metrology.

Although no MMW work has been initiated in the areas of phase noise or properties of materials, there is sufficient need and interest, and NBS is optimistic of obtaining support to initiate projects in these areas [20]. Requests for pulsed power measurement standards continue to be voiced but the range of frequencies and power levels has been too diffuse to warrant serious planning in light of the many other higher priority tasks to be performed.

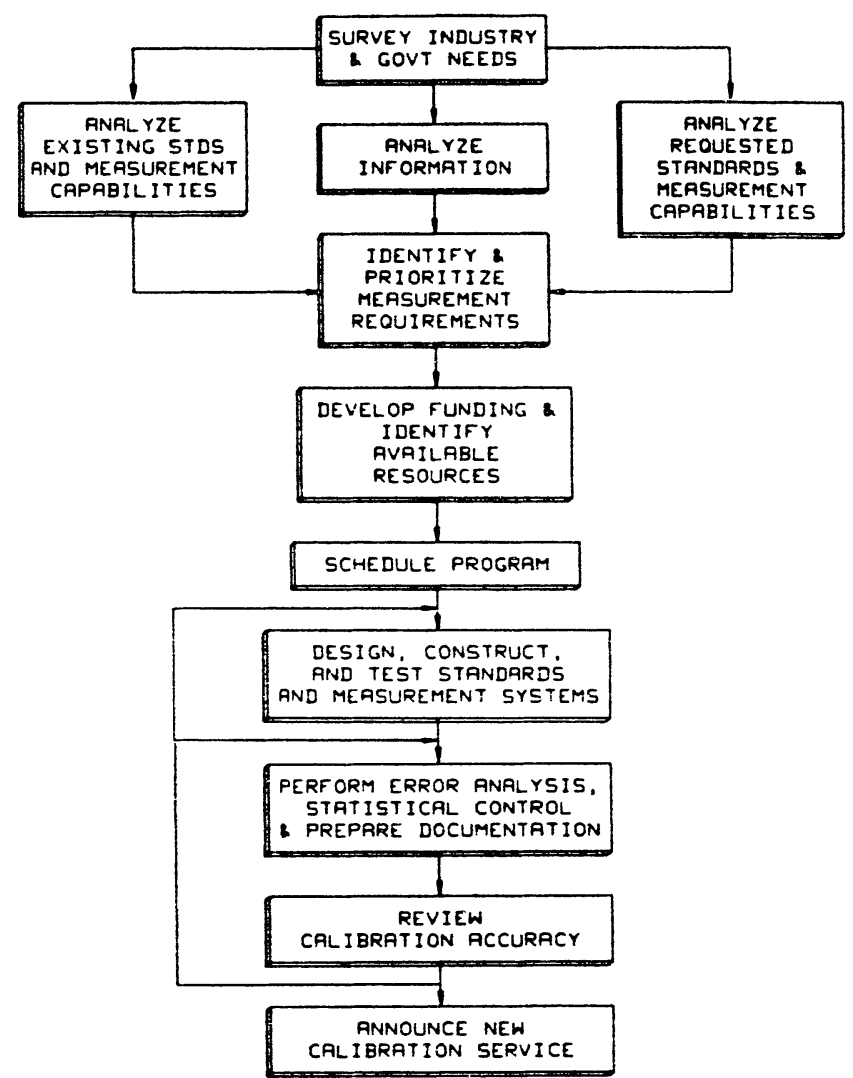

Fig. 6. Flow diagram illustrating the process of developing new calibration services at NBS.

\section{ViI. Challenges in Meeting National Measurement NeEdS}

Identifying, verifying, and establishing the priority of real measurement needs and then developing a new measurement service can pose significant problems for metrologists. Fig. 6 is a flow diagram which illustrates the general procedure to establish new measurement services at NBS. This process is both complex and time consuming, and requires the close cooperation of the measurement community, including industry and the DoD. Adequate in-depth error analysis and system quality assurance controls are extremely important parts of the development of a new standard of measurement service. Complete documentation of a system or service must be completed and approved by NBS prior to its public announcement. These important tasks, which are necessary to complete the picture, add greatly to the time required to provide new services.

These challenges, together with today's rapidly advancing technology, make it necessary to anticipate the required future measurement services and needed accuracies from five to ten years in advance [21]-[23].

\section{ACKNOWLEDGMENT}

The authors wish to express their sincere appreciation for assistance from the staff of the Electromagnetic Fields Division for providing the NBS measurement capabilities 
data, the PNMS Committee, CCG, and NCSL for the use of their survey results, and many staff members of the Naval Research Laboratory, the Naval Oceans Systems Center, TRW Electronic Systems Group, Rockwell International, General Dynamics, Hughes, and Georgia Institute of Technology Research Institute for contributing to the measurement requirements database.

\section{REFERENCES}

[1] "National Bureau of Standards-Answers to congressional concerns," in "Report by the Comptroller General of the United States," U.S. General Accounting Office, Rep. CED-80-49, pp. 11-12, Feb. 2, 1980.

[2] "Preliminary report, IEEE Comm. Promotion Nat. Microwave Standards," presented at the Dep. of Defense Sem. Millimeter-Wave Meas. Requirements, Harry Diamond Labs., Adelphi, MD. Apr. 1985.

[3] "Oveniew of microwave/millimeter wave programs," in "National Measurement Requirements Survey, " Nat. Conf. Standards Lab. Nat. Measurement Requirements Comm., Rep. NMRC 83-01, May 1983. pp. 2C-5-2C-14.

14] Tri-Service Metrology Research. Development, and Engineering Plan, CCG Engineering Working Group, June 6, 1984, pp. 21-22.

[5] A. E. Braun, "MM-wave threats continue to grow." in "Microwave Systems Designer's Handbook," Microwave Systems Nen's, vol. 13, no. 12 , Nov. 1983.

16] P. G. Mezger. "Radio astronomy looks at higher frequencies," Microwave Systems New's, vol. 14. no. 1, pp. 95-129. Jan. 1984.

[7] "Notice of intent for experiments," Advanced Communications Technology Satellite (ACTS), NASA, Mar. 1983, rev. Nov. 1984.

[8] "Experiments meeting digest." Advanced Communications Technology Satellite (ACTS). NASA. Mar. 1985

[9] J. Gallagher, "Current and future millimeter wave measurement needs," Millimeter Wave Division. Georgia Inst. Technol. Res. Inst.. Atlanta. GA. private communication.
[10] IEEE MTT-S 10th Annu. Int. Conf. Infrared and Millimeter-Waves Dig. (Lake Buena Vista, FL), Dec. 8-13, 1985.

[11] Nat. Aeronautics and Space Admin. Millimeter Conf. Dig. (Greenbelt, MD), Mar. 6-7, 1985.

[12] IEEE MTT-S Int. Microwave Symp. Dig. (San Francisco, CA), May 30-June 1, 1984.

[13] IEEE MTT-S Int. Microwave Symp. Dig. (St. Louis, MO), June 4-6, 1985.

[14] M. Kachmar, "The impending crisis in microwave metrology," Microwaves \& $R F$, vol. 24, no. 6, pp. 37-45, June 1985 .

[15] M. Kachmar, "The NBS sets its sights on better measurement services," Microwaves \& RF, vol. 24, no. 7, pp. 34-92, July 1985.

[16] B. Belanger, Ed., "Millimeter wave measurement requirements," presented at the Sem. Millimeter Wave Meas. Requirements, Harry Diamond Labs., Adelphi, MD, Mar. 20-21, 1984 (Part I-Unclassified).

[17] B. Belanger, Ed., “Millimeter wave measurement requirements," presented at the Sem. Millimeter Wave Meas. Requirements, Harry Diamond Labs., Adelphi, MD, Apr. 1985 (Part I-Unclassified).

[18] G. A. Uriano. E. L. Garner, R. K. Kirby, and W. P. Reed, Eds., NBS Calibration Services Users Guide 1986-1988 Edition. Nat. Bur. Stand. (U.S.), Spec. Pub. 250, July 1986. (New editions published every two years). Appendix (price and current availability listing) to Spec. Pub. 250 published every six months.

[19] L. T. McClendon and R. K. Kirby. Eds., "NBS physical measurement services status report," Nat. Bur. Stand. (U.S.), Rep. NBSIR 84-2875, 1984.

[20] Board on Assessment of NBS Programs, "An evaluative report on the National Engineering Laboratory, National Bureau of Standards," National Research Council, Fiscal Year 1985, p. 47.

[21] J. Fitzpatrick, "NBS and microwave metrology-Growing concern within the industry," Microwave Systems News, vol. 14, p. 48, May 1984.

[22] S. L. Johnston, "Radar frequency management and the new mm-wave radar operating frequencies, " Microwave J. (Special Report), pp. 36, $38,40,42,44,1984$.

[23] R. Pidgeon, "The need for thermal noise standards in the 18 to 60 GHz region." Westinghouse Defense and Electronics Center, Baltimore. MD, private communication. 